\title{
Fiscal sustainability analysis in EU countries: a dynamic macro-panel approach
}

\author{
Gözde Eş POLAT*, Onur POLAT***
}

\begin{abstract}
In this work, we analyze fiscal sustainability for 26 EU and PIIGS countries in terms of Bohn's (2008) approach. In this context, we use primary surplus-to-GDP, public debt-to-GDP, government revenues/expenditures-to-GDP, business cycle, and fluctuations in government expenditures variables in the period 1995-2018. A positive and long-run relationship between lagged public debt and primary surplusto-GDP indicates that fiscal policy is sustainable for the EU, overall. However, the fiscal sustainability criterion is not met for the PIIGS since the transversality condition is not met. Empirical findings of the study underline an effective regulatory policy framework to monitor fiscal policy developments for both core and periphery EU states.
\end{abstract}

Keywords: Fiscal Sustainability, Intertemporal Budget Constraint, Panel Data Analysis

\section{Introduction}

Throughout the financialization and globalization era, both emerging and advanced countries have faced deep and severe financial/real crises and they have implemented different fiscal policy actions to mitigate the adverse effects of the crises, accordingly. In this context, the notion fiscal sustainability has been the focus of both policymakers and scholars and fiscal sustainability studies have gained momentum, particularly after the 1970s. Furthermore, emerging and advanced countries have implemented different fiscal policy actions (expansionary or contractionary) to abate the hazardous effects of the crises and to recover from them.

Despite the monetary union joined by most European Union (EU) members, overall, there is no common fiscal policy supported in the EU. This leads to different fiscal policy actions implemented by core/periphery EU states during financial crises

\footnotetext{
* Gözde Eş POLAT is a Research Assistant, Bilecik Seyh Edebali University, Bilecik, Turkey; e-mail: gozde.es@ bilecik.edu.tr (corresponding author).

** Onur POLAT is an Assistant Professor, PhD, Bilecik Seyh Edebali University, Bilecik, Turkey; e-mail: onur.polat@bilecik.edu.tr.
} 
to alleviate the crises' adverse effects. To exemplify, the core EU states performed expansionary fiscal policies during the 2007-09 global financial crisis (GFC) and the 2010-12 European Sovereign Debt Crisis (ESDC), albeit periphery EU states implemented contractionary fiscal policies (Polat and Polat, 2019). Notwithstanding a fiscal union joined by all EU members, a sustainable fiscal policy is crucial to ensure a healthy fiscal and macroeconomic system in the EU, overall. Despite the fact that EU states are subject to the same fiscal policy framework determined by the Maastricht Treaty, the Stability and Growth Pact, and the Fiscal Compact, they have performed different fiscal policy responses (Dragutinović et al., 2019).

In the light of heterogeneous fiscal policy actions carried out by the core/periphery EU states, this study aims to analyze fiscal sustainability for $26 \mathrm{EU}$ and PIIGS countries by utilizing Bohn's (2008) model-based approach using primary-to-GDP ratios, public debt-to-GDP ratios, government revenues/expenditures (GDP\%). Furthermore, we examine cyclical effects by using the business cycle (YVAR) and fluctuations in government expenditure (GVAR) variables.

Our main hypotheses for this study are as follows. First, in line with previous studies, such as Afonso and Rault (2010) and Brady and Magazzino (2018), there exists a significant long-run relationship between government expenditures and revenues and thus the fiscal sustainability is met for the panel set of EU countries. Second, since our data period covers the European Sovereign Debt Crisis (ESDC) and the crisis sorely hit the peripheral states, particularly the PIIGS countries, we expect the absence of fiscal sustainability for the PIIGS countries consistent with Brady and Magazzino (2018).

The rest of the study is organized as follows: Section 2 presents theoretical and empirical works on fiscal sustainability. Section 3 provides the theoretical framework of the work. Section 4 presents the data, the methodology and discusses the empirical findings. Finally, Section 5 summarizes the main findings of the study and concludes it.

\section{Literature Review}

Both emerging and advanced economies faced the 1970s financial/real crises, which conduced to payment difficulties and worsened fiscal/macroeconomic conditions. Hereby, governments have concentrated on fiscal sustainability which has become one of governments'main objectives. Following the debt crises of the 1990s, scholars and policymakers have focused on fiscal sustainability to protect economy against the crises' detrimental effects. Additionally, it is worthwhile noting that, if a country meets the fiscal sustainability criterion, the systemic risk of this country is lower, and hereby the macroeconomic conditions of this country are better. As a consequence, meeting the fiscal sustainability criterion is crucial for economies. 
There is no reconciliation on the definition of fiscal sustainability and indicators to test fiscal sustainability, the common ground of the related literature is Domar's (1944) study. Domar's fiscal sustainability condition stipulates convergence of the public debt ratio to finite value to prevent continuous rising in the tax burden (Domar, 1944).

Studies have focused on fiscal sustainability both theoretically and empirically. In some theoretical studies, fiscal sustainability is examined regarding "sustainability of the public debt". Another strand of studies labels fiscal sustainability with the sustainability of debt deficits. Five different approaches theoretically analyze fiscal sustainability, namely, the Accounting approach, the Intertemporal Budget Deficit Constraint approach, the Present Value Constraint (PVC) approach, the Sudden Stop approach, the Probabilistic approach, and the Human Development approach.

In the Accounting approach, fiscal sustainability is analyzed based on macroeconomic indicators. The macroeconomic indicators used in this approach are the public sector net worth-to-GDP ratio (Bruiter, 1985) and the public debt-to-GDP ratio (Blanchard, 1990). This approach examines fiscal sustainability by testing whether those ratios converge back to their initial values (Blanchard et al., 1991).

Hamilton and Flavin developed the Intertemporal Budget Deficit Constraint approach. The authors analyzed fiscal sustainability for the US by using the postWW2 macroeconomic data and argued that the fiscal policy is sustainable despite budget deficits (1986, p. 818). Calvo et al. (2003) introduced the Sudden Stop approach to determine an explanation for the fall of Argentina's Convertibility Program. The authors pointed out that Argentina's Sudden Stops were triggered by the 1998 Russian crisis owing to heavily dollarized liabilities and led to an unsustainable fiscal position.

Mendoza and Oviedo (2003) developed the Probabilistic approach, which is a dynamic stochastic general equilibrium (DSGE) model. In the model, the path of government revenues is endogenously specified by the utility-maximizing households and profit-maximizing firms, based on producing tradable and nontradable goods. The authors argued that there is a mismatch in the government's balance sheet since the government debt mainly consists of tradable goods and tax revenues mostly include non-tradable goods.

Sachs (2002) introduced the Human Development approach. This model assumes that low-income countries are vulnerable to the poverty trap, which can be propelled by an excessive foreign debt burden. The author argued that resources should be allocated to public sector investments in basic human capital to alleviate poverty and to ensure a sustainable fiscal policy.

These aforementioned approaches can also be classified into static and dynamic. Accounting and Intertemporal Budget Constraint approaches are static ones focusing on government revenue and expenditure levels, whereas other approaches that examine the relationship between growth rate and budget indicators 
by employing partial or general equilibrium models are dynamic (Slack and Bird, 2004, p. 4; Siriwardana, 1998, pp. 82-85). In this study, we implement a static fiscal sustainability model, namely, the Intertemporal Budget Constraint approach.

An extensive number of studies have empirically analyzed fiscal sustainability in terms of the Intertemporal Budget Constraint approach. These studies can be classified into two different categories. The first category consists of studies that analyze fiscal sustainability by focusing on time-series characteristics (stationarity, co-integration) of fiscal indicators (budget revenues, budget expenditures). Within this group, studies propose that if there exists a long-run relationship (co-integration) between government revenues and government expenditures, the fiscal sustainability criterion is met. The second category finds stationarity and co-integration analyses inadequate and argues that fiscal sustainability can be investigated by fiscal reaction functions (FRFs), which are the regression models of causality between fiscal policies of policymakers and public debt ratios. Both categories assume that the NoPonzi game condition ${ }^{59}$ is the necessary and sufficient condition for fiscal sustainability. The empirical studies on fiscal sustainability are presented in Table 1 .

The 2000s studies in the first category examined fiscal sustainability for different countries. Among them, Afonso (2005) analyzed fiscal sustainability for the EU-15 by using government public debt, price deflator of final private consumption expenditure, government total revenues/expenditures, and gross domestic product data in 1970-2003. The empirical findings of the study reveal that, except for some countries (Austria, Germany, Finland, Netherlands, and Portugal), fiscal stability is met for the EU-15 (Afonso, 2005). In a similar vein, Prohl and Schineder (2006) analyzed fiscal sustainability for the EU-15 by employing panel co-integration between primary budget deficits and public debt-to-GDP ratios between 1970 and 2004. The authors argued that fiscal sustainability is accepted for the EU-15 over the analyzed period. Likewise, Claeys (2007) examined fiscal sustainability for 14 EU states (Austria, Belgium, Denmark, Germany, Spain, Finland, France, Great Britain, Greece, Ireland, Italy, the Netherlands, Portugal, and Sweden) by using real government expenditures/revenues and real net interest payments in 1970-2001. Stationarity and co-integration analyses indicate that fiscal policy is sustainable for $14 \mathrm{EU}$ states overall, yet fiscal policy is not sustainable at the national level (Claeys, 2007).

59 No-Ponzi Game condition is the necessary condition for the Intertemporal Budget Constraint approach and "is satisfied when the budget deficit is integrated of order one, therefore, distinguishes between strong (the budget deficit is stationary) and weak (the budget deficit is nonstationary) forms of solvency" (Bergman, 2001, p. 27). 
Table 1. Empirical Studies on Fiscal Sustainability

\begin{tabular}{|c|c|c|c|c|}
\hline Study & $\begin{array}{l}\text { Frequency } \\
\text { of } \\
\text { Variables }\end{array}$ & $\begin{array}{l}\text { Date and } \\
\text { Country }\end{array}$ & Metodology and Data Set & $\begin{array}{l}\text { Fiscally } \\
\text { sustainable? }\end{array}$ \\
\hline $\begin{array}{l}\text { Hamilton and Flavin } \\
(1986)\end{array}$ & Annual & $\begin{array}{l}1962-1984 \\
\text { (US) }\end{array}$ & $\begin{array}{l}\text { Stationarity Analysis (Budged } \\
\text { deficit and public debt) }\end{array}$ & Yes \\
\hline $\begin{array}{l}\text { Trehan and Walsh } \\
(1988)\end{array}$ & Annual & $\begin{array}{l}1890-1983 \\
\text { (US) }\end{array}$ & $\begin{array}{l}\text { Stationarity Analysis (Budged } \\
\text { deficit) }\end{array}$ & Yes \\
\hline Kremers (1988) & Annual & $\begin{array}{l}\text { 1920-1985 } \\
\text { (US) }\end{array}$ & $\begin{array}{l}\text { Stationarity Analysis (Public } \\
\text { debt) }\end{array}$ & $\begin{array}{l}\text { Before } 1981- \\
\text { Yes } \\
\text { After } 1981 \text { - No }\end{array}$ \\
\hline $\begin{array}{l}\text { Elliot and Kearney } \\
\text { (1988) }\end{array}$ & Annual & $\begin{array}{l}1953 / 54- \\
1986 / 87 \\
\text { (Australia) }\end{array}$ & $\begin{array}{l}\text { Co-Integration Analysis (Budget } \\
\text { revenues/expenditures) }\end{array}$ & Yes \\
\hline Wilcox (1989) & Annual & $\begin{array}{l}\text { 1960-1984 } \\
\text { (US) }\end{array}$ & $\begin{array}{l}\text { Stationarity Analysis (Public } \\
\text { debt) }\end{array}$ & No \\
\hline $\begin{array}{l}\text { MacDonald and } \\
\text { Speight (1990) }\end{array}$ & Annual & $\begin{array}{l}\text { 1961-1986 } \\
\text { (UK) }\end{array}$ & $\begin{array}{l}\text { Stationarity Analysis (Public } \\
\text { debt), Co-Integration Analysis } \\
\text { (Budget deficit and public debt) }\end{array}$ & Inconclusive \\
\hline $\begin{array}{l}\text { Hakkio and Rush } \\
\text { (1991) }\end{array}$ & Quarterly & $\begin{array}{l}\text { 1959:II- } \\
\text { 1988:IV } \\
\text { (US) }\end{array}$ & $\begin{array}{l}\text { Co-Integration Analysis (Budget } \\
\text { revenues/expenditures) }\end{array}$ & No \\
\hline Smith and Zin (1990) & Monthly & $\begin{array}{l}1946: 1- \\
1984: 12 \\
\text { (Canada) }\end{array}$ & $\begin{array}{l}\text { Stationarity Analysis (Public } \\
\text { debt), Co-Integration Analysis } \\
\text { (Budget deficit and public debt) }\end{array}$ & No \\
\hline $\begin{array}{l}\text { Trehan and Walsh } \\
\text { (1990) }\end{array}$ & Annual & $\begin{array}{l}\text { 1960-1984 } \\
\text { (US) }\end{array}$ & $\begin{array}{l}\text { Co-Integration Analysis (Budget } \\
\text { revenues/expenditures) }\end{array}$ & Yes \\
\hline Caporale (1995) & $\begin{array}{l}\text { Semi- } \\
\text { Annual } \\
\text { and } \\
\text { Annual }\end{array}$ & $\begin{array}{l}1960-1991 \\
\text { (EU } \\
\text { Countries) }\end{array}$ & $\begin{array}{l}\text { Stationarity Analysis (Public } \\
\text { debt and budget deficit) }\end{array}$ & $\begin{array}{l}\text { No for Italy, } \\
\text { Greece, Denmark, } \\
\text { and Germany }\end{array}$ \\
\hline $\begin{array}{l}\text { Makryradis et al. } \\
\text { (1999) }\end{array}$ & Annual & $\begin{array}{l}1958-1995 \\
\text { (Greece) }\end{array}$ & $\begin{array}{l}\text { Stationarity Analysis (Public } \\
\text { debt) }\end{array}$ & No \\
\hline $\begin{array}{l}\text { Greiner and Semmler } \\
\text { (1999) }\end{array}$ & Annual & $\begin{array}{l}1955-1994 \\
\text { (Germany) }\end{array}$ & $\begin{array}{l}\text { Stationarity Analysis (Public } \\
\text { debt) }\end{array}$ & No \\
\hline
\end{tabular}

Source: Afonso (2005, pp. 26-27).

Studies in the second category have employed the model-based sustainability (MBS) approach proposed by Bohn (1995; 1998). Bohn (1995) developed a Dynamic Stochastic General Equilibrium (DSGE) model to analyze long-term fiscal sustainability. The model employs the Intertemporal Budget Constraint approach that consists of the discounted future government spending and taxes (Bohn, 1995). Along similar lines, Bohn (1998) analyzed fiscal sustainability for the US by using primary surplus and public debt in 1916-1995 and found that fiscal policy is sustainable (Bohn, 1998).

Among studies in the second category, Ghatak and Sánchez-Fung (2007) investigated fiscal sustainability for South Africa, the Philippines, Peru, Thailand, 
and Venezuela in 1970 and 2000. The findings of the study indicate that fiscal policy is sustainable for Thailand, whereas the estimations are statistically insignificant for other countries (Ghatak and Sánchez-Fung, 2007). Bohn (2008) examined fiscal sustainability for the US by utilizing the MBS approach of Bohn $(1995 ; 1998)$ between 1792 and 2003. The positive long-run relationship between primary surplus and public debt reveals that fiscal policy is sustainable for the US in 1792-2003 (Bohn, 2008). Likewise, Claeys et al. (2008) analyzed fiscal sustainability at national and state levels for the US in 1962-2000 and Germany in 1970-2005 using fiscal variables. The authors argued that fiscal sustainability is met for the US in 19622000, whereas fiscal policy is not sustainable for Germany in 1970-2005 (Claeys et al., 2008).

Sakuragawa and Hosono (2011) analyzed fiscal sustainability for Japan by employing a DSGE model in 1982 and 2009. According to the empirical results of the study, if the government does not respond to a fiscal crisis, which leads to an increase in public debt/GDP ratio, fiscal sustainability is not met (Sakuragawa and Hosono, 2011). Mahdavi (2014) examined fiscal sustainability for 48 US states by employing Bohn's (1998) approach using primary surplus ratio, public debt ratio, state expenditures, and Federal Grant Rate in 1961-2008 and argued that fiscal policy is sustainable (Mahdavi, 2014). In a similar vein, Potrafke and Reichmann (2015) investigated fiscal sustainability for the US states in 1978-2010 and the German Federal States in 1975-2010 by applying Bohn's (1998) model. According to the findings of the study, if the transfer payments are not added to the primary surplus, fiscal policy is sustainable for both the US and the German Federal States (Potrafke and Reichmann, 2015). Cascio (2015) analyzed fiscal sustainability for the US by employing Bohn's (1998) model and the Wavelet analysis in 1792-2012. Empirical results of the study indicate that fiscal policy is sustainable until 1995 (Cascio, 2015). More recently, Feld et al. (2020) focused on fiscal sustainability for 16 German Federal States by implementing Bohn's (1998) approach and argued that the fiscal sustainability criterion is partially met (Feld et al., 2020).

\section{Theoretical Framework}

Feld et al. (2020) concentrate on the long-run fiscal sustainability by relying? on the Intertemporal Government Budget Constraint (IGBC). The IGBC imposes that "government debt equals discounted government surplus and discounted future government debt" (Feld et al., 2020, p. 218). The IGBC is given in Equation 1 as follows:

$$
d_{0}=-\sum_{t=1}^{\infty}\left(\frac{1+y}{1+r}\right)^{t} p_{t}+\lim _{T \rightarrow \infty}\left(\frac{1+y}{1+r}\right)^{T} d_{T}
$$

In Equation $1, d_{0}, d_{T}$ represent the government debt and the discounted future government debt, respectively. $p_{t}$ corresponds to the government surplus at time $t$. 
$r$ is the interest rate and $y$ is the growth rate. The first complementary condition is the transversality condition, which involves

[...] whether the second term on the right-hand side (r.h.s.) is met. This condition imposes the discounted present value of public debt to converge zero an infinite timeline. The transversality condition employs unit root and stationarity tests for fiscal variables, such as public debt and budgetary and primary surpluses. The second condition is to test the first term on the r.h.s. of Equation 1. If this condition is met, then the government has to accumulate sufficient primary surpluses to finance its debt (Feld et al., 2020, p. 218).

It is worthwhile to note that the time-series analysis for testing the transversality condition is to implement unit root tests for fiscal variables. In this context, before examining the long-run FRFs, we perform unit root analysis for fiscal variables and accordingly test the transversality condition.

\section{Data, methodology and empirical results}

In this study, we use primary surplus-to-GDP ratios, public debt-to-GDP ratios, government revenues (GDP\%), government expenditures (GDP\%) for $26 \mathrm{EU}$ states $^{60}$ in $1995-2018^{61}$. The dataset of the study is obtained from the ECB Eurosystem Statistical Data Warehouse (ECB Eurosystem Statistical Data Warehouse, 2020 ${ }^{62}$. Public debt/GDP ratios for $26 \mathrm{EU}$ states between 1995-2018 are depicted in Figure A.1 in the Appendix.

Public debt-to-GDP ratios are below 1 for most of the EU states and mainly stable in 1995-2018 (Austria, Czech Republic, Estonia, France, Finland, Germany, the Netherlands, Spain, Sweden, Latvia, Lithuania, Luxembourg, Hungary, Malta, Poland, Romania, Slovakia, Slovenia, and the UK). On the other hand, public debtto-GDP ratios for the PIIGS (Portugal, Ireland, Italy, Greece, and Spain) dramatically surged during the European Sovereign Debt Crisis (ESDC). The public debt-to-GDP ratio for Bulgaria exceeded 200\% during the 1990s, yet it has stabilized in the recent period.

The deterioration of fiscal position and surging government debts in the EU following the 2008 global financial crisis (GFC) rendered fiscal sustainability a vital policy challenge for EU policymakers (European Commission, 2017). In view of this, scholars have extensively analyzed overall fiscal sustainability in the EU

\footnotetext{
${ }^{60}$ Austria, Belgium, Bulgaria, Cyprus, Czech Republic, Estonia, France, Finland, Germany, Greece, Hungary, Ireland, Italy, Latvia, Lithuania, Luxemburg, Malta, the Netherlands, Poland, Portugal, Romania, Slovakia, Slovenia, Spain, Sweden, and the United Kingdom. Denmark and Croatia could not be included in the analysis due to the lack of data.

${ }^{61}$ Summary statistics for the dataset are given in Table A.1, Table A.2, Table A.3., and Table A.4 in the Appendix.

${ }^{62}$ Stata 14.0 is used to estimate the empirical results of the study.
} 
(Dolenc and Stubej1, 2010; Berrittella and Zhang, 2015; Lee et al., 2018; Mackiewicz-Łyziak and Łyziak, 2019; Ramos-Herrera and Prats, 2020). In line with these studies, in the first stage, we examine fiscal sustainability for the panel of 26 EU states.

It should be noted that the ESDC sorely hit the PIIGS economies mostly due to fiscal deficits, public debt problems (Alexakis and Pappas, 2018). In line with this phenomenon, scholars have focused on the fiscal sustainability for the PIIGS countries by clustering the EU states (Brady and Magazzino, 2018), or employing a time-varying stock-flow system (Neto, 2020). Our main motivation for examining the fiscal sustainability for the PIIGS countries in the second stage is three-folded. First, as clearly shown in Figure A.1, the PIIGS countries confronted with considerable high public debt ratios during the GFC and could not improve their fiscal structure after the GFC despite bailouts implemented by the EU or IMF. Second, the ESDC mainly stemmed from the unfavorable fiscal/macroeconomic conditions of the periphery EU states covering the PIIGS. Third, the PIIGS' public debt ratios have remained high in the post-ESDC epoch and these countries are different from the core EU states in terms of their fiscal structure. Since the public debt-to-GDP ratio is a key indicator for fiscal sustainability, we particularly focus on the PIIGS in the second stage of the study. Our main contribution to the extant literature is to analyze fiscal sustainability for the overall EU and PIIGS levels by allowing slope heterogeneity and cross-sectional dependence in dynamic panel models. Furthermore, we estimate the long-term fiscal reaction functions (FRFs) to detect unobserved heterogeneous business and fiscal policy cyclical effects.

We follow the studies of Bohn (2008) and Feld et al. (2020) and analyze fiscal sustainability by employing the regression model given as follows:

$$
\begin{aligned}
\text { Primary SurplustoGDP }_{i t}= & \alpha \text { Public DebttoGDP } \\
& b_{i}+\beta \text { Control }_{i t}+v_{i t}
\end{aligned}
$$

In Equation 2, the dependent variable in the regression model is the primary surplus-to-GDP ratio, and the independent variable is the lagged public debt-to-GDP ratio for each EU state. Equation 2 involves variables to control for cyclical effects, namely temporary fluctuations of government expenditures by the GVAR, and tax smoothing by the business cycle YVAR (Barro, 1986).

Barro (1986) examined the determination of deficits for the US between 1916 and 1982 in his seminal paper. To this end, he introduced the cyclical variable YVAR based on a measure of temporary shortfall of output, $\left(1-\frac{y_{t}}{y_{t T}}\right)$ and the ratio of normal real government spending to real taxable income $\frac{g_{t T}}{y_{t}}$. He also defined the cyclical variable GVAR by relying on the temporary real government spending $g_{t-} g_{t T}$. 
YVAR and GVAR are specified as follows:

$$
\begin{gathered}
Y V A R_{i t}=\left(1-\frac{y_{t}}{y_{t T}}\right) * \frac{g_{t T}}{y_{t}} \\
G V A R_{i t}=\frac{\left(g_{t-} g_{t T}\right)}{y_{t T}}
\end{gathered}
$$

In Equation 3, 4; $y_{t}, y_{t T}$ represent the real output and Hodrick Prescott (HP) (1997)-filtered trend of output, respectively. Likewise, $g_{t}, g_{t T}$ correspond to the public debt and HP-filtered trend of the public debt, respectively. It should be noted that if the current output is larger than the HP-filtered trend of the output, the YVAR takes negative values. Similarly, if the current expenditures are larger than its trend, the GVAR takes negative values. Summary statistics of GVAR and YVAR are given in Table A.5 and Table A.6 in the Appendix.

In line with the theory, we expect a negative correlation between YVAR, GVAR, expenditure, and the primary surplus.

Firstly, we test the stationarity of primary surplus-to-GDP ratio, public debtto-GDP ratio, government revenues, government expenditures by implementing the second generation panel unit root tests. The first generation panel data studies neglected the cross-sectional dependence of the panel variables. However, crosssectional dependence may lead to inaccurate panel data estimations (fixed or random models, generalized method of moments) and an unexpected shock may be correlated with an independent variable in the model (Andrews, 2005; Sarafidis and Robertson, 2009). Therefore, we first analyze the cross-sectional dependence of the panel data set.

\subsection{Cross-Sectional Dependence Test}

The first generation panel data studies neglected cross-sectional dependence between units of the panel data sets. However, a rapid increase in global data accessibility has led the literature to evolve to panel models, which include large panel datasets that may have a cross-sectional dependence between units of micropanel models (Chudik and Pesaran, 2013).

In this study, cross-sectional dependence between units in the panel data set is tested by employing The Pesaran (2004) CD (cross-sectional dependence) test. Pesaran (2004) introduced the CD as follows:

$$
C D=\sqrt{\frac{2 T}{N(N-1)}}\left(\sum_{I=1}^{N-1} \sum_{j=i+1}^{N} \hat{\rho}_{i j}\right) \sim N(0,1) i, j=1, \ldots, N
$$


In Equation 5, $\hat{\rho}_{i j}$ is the estimation of pairwise correlation of the residuals. The CD test results for primary surplus-to-GDP ratios, public debt-to-GDP ratios, government revenues, government expenditures, YVAR, and GVAR are given in Table 2.

Table 2. CD Test Results

\begin{tabular}{ll}
\hline \multicolumn{1}{c}{ Variables } & CD Test \\
\hline Primary Surplus-to-GDP Ratios & $27.463^{* * *}$ \\
\hline Lagged Public Debt-to-GDP Ratios & $26.603^{* * *}$ \\
\hline Government Revenues (GDP \%) & $8.654^{* * *}$ \\
\hline Government Expenditures (GDP \%) & $21.629^{* * *}$ \\
\hline YVAR & $31.097^{* * *}$ \\
\hline GVAR & $26.721^{* * *}$
\end{tabular}

Note: ${ }^{* * *},{ }^{* * *}$ represent $10 \%, 5 \%$ and $1 \%$ significance levels, respectively. The null hypothesis is the cross-sectional independence.

Source: Authors' representation

According to the results in Table 2, the CD test rejects cross-sectional independence for all series at a $1 \%$ significance level. As stated by Pesaran, the CD test results are "correctly centered for fixed $N$ and $T$, and robust to single or multiple breaks in the slope coefficients and/or error variances" (Pesaran, 2004, p.14). Thereupon, the CD test results suggest using the second generation panel unit root tests.

\subsection{Panel Unit Root Test}

We test the stationarity of the series by employing the Pesaran (2007) CADF (Cross-sectionally Augmented Dickey-Fuller) test due to the existence of crosssectional dependence between panel units. Pesaran (2007) introduced a regression model that adds the levels of the cross-sections and the first differences of the series to the standard ADF regressions. According to the model, the panel unit root test $\mathrm{CADF}$ is defined as follows:

$$
\Delta y_{i t}=a_{i}+b_{i} y_{i, t-1}+c_{i} \bar{y}_{t-1}+d_{i} \Delta \bar{y}_{t}+\varepsilon_{i t}
$$

Pesaran's CADF test results are presented in Table 3.

Table 3. CADF Panel Unit Root Tests

\begin{tabular}{lll}
\hline & CADF Test & \\
\hline Variables & Constant & Constant + Trend \\
\hline Primary Surplus-to-GDP & $-1.766(0.466)$ & $-2.182(0.759)$ \\
\hline
\end{tabular}




\begin{tabular}{lll}
\hline Public Debt-to-GDP & $-1.943(0.157)$ & $-2.644(0.034)$ \\
\hline Government Revenues (GDP \%) & $-2.120(0.027)$ & $-2.179(0.763)$ \\
\hline Government Expenditures (GDP \%) & $-2.137(0.022)$ & $-2.490(0.162)$ \\
\hline YVAR & $-2.754(0.000)$ & $-2.764(0.006)$ \\
\hline GVAR & $-3.071(0.000)$ & $-3.334(0.005)$ \\
\hline
\end{tabular}

Note: ${ }^{* * *},{ }^{* * *}$ represent $10 \%, 5 \%$ and $1 \%$ significance levels, respectively.

Source: Authors' representation

The CADF test results are asymptotically_similar and invariant to the factor loadings (Pesaran, 2007), and thereby robust. The CADF test is estimated with optimal lag length 2 that is determined by the Hansen (1982) test statistic in the panel VAR model. The CADF test results indicate that without time trend, all series are $I(1)$. Both the control variables the YVAR and the GVAR are stationary in their level form as expected.

\subsection{Westerlund Panel Co-Integration Test} as follows:

Westerlund (2007) introduced the co-integration model for the panel data set

$$
\begin{gathered}
y_{i t}=\varphi_{1 i}+\varphi_{2 i} t+z_{i t} \\
x_{i t}=x_{i t-1}+v_{i t}
\end{gathered}
$$

Herein, $t=1, \ldots, T$ and $i=1, \ldots, N$ represent time and section units.

$K$-dimensional vector $x_{i t}$ is defined as a random walk model. $y_{i t}$ consists of deterministic $\left(\varphi_{1 i}+\varphi_{2 i} t\right)$ and stochastic $z_{i t}$ terms and presented as follows:

$$
\alpha_{i}(L) \Delta y_{i t}=\alpha_{i}\left(y_{i t-1}-\beta_{i}^{\prime} x_{i t-1}\right)+\gamma_{i}(L)^{\prime} v_{i t}+e_{i t}
$$

In Equation 9, $\alpha_{i}(L)=1-\sum_{j=1}^{p_{i}} \alpha_{i j} L^{j}$ and $\gamma_{i}(L)=\sum_{j=0}^{p_{i}} \gamma_{i j} L^{j}$ are $K$ dimensional polynomial for the lag operator $L$. By substituting (8) in (9) we obtain the following error-correction model.

$$
\alpha_{i}(L) \Delta y_{i t}=\alpha_{i}\left(y_{i t-1}-\beta_{i}^{\prime} x_{i t-1}\right)+\gamma_{i}(L)^{\prime} v_{i t}+e_{i t}
$$

In Equation (10), $\delta_{1 i}=\alpha_{1}(i) \varphi_{2 i}-\alpha_{i} \varphi_{1 i}+\alpha_{i} \varphi_{2 i}$ and $\delta_{2 i}=-\alpha_{i} \varphi_{2 i}$ represent the deterministic components.

Following Feld et al. (2020), we estimate the state-specific fiscal reaction functions (FRF) by analyzing co-integration between primary surplus-to-GDP ratios and public debt-to-GDP ratios, and co-integration between government revenues and 
government expenditures. In this context, we apply the Westerlund Panel CoIntegration test. It should be noted that we implement the bootstrap resampling procedure at 400 re-estimations for each Westerlund panel cointegration test and hence, the test provides robust estimations. The test results are presented in Table 4.

\section{Table 4. Westerlund Panel Co-Integration Test Results}

\begin{tabular}{llll}
\hline \multicolumn{4}{c}{ Westerlund Panel Co-Integration Test Results } \\
\hline Variables & Test Results & \\
\hline Primary Surplus-to-GDP & $\mathrm{G}_{\mathrm{t}}:-4.003$ & $(0.000)$ & $\mathrm{P}_{\mathrm{t}}:-28.294(0.000)$ \\
Lagged Public Debt-to-GDP & $\mathrm{G}_{\mathrm{a}}:-23.41$ & $(0.000)$ & $\mathrm{P}_{\mathrm{a}}:-24.677(0.000)$ \\
\hline Government Revenues (GDP\%) & $\mathrm{G}_{\mathrm{t}}:-4.030$ & $(0.000)$ & $\mathrm{P}_{\mathrm{t}}:-22.985(0.000)$ \\
Government Expenditures (GDP\%) & $\mathrm{G}_{\mathrm{a}}:-18.68$ & $(0.033)$ & $\mathrm{P}_{\mathrm{a}}:-17.732(0.000)$ \\
\hline
\end{tabular}

Source: Authors' representation

As shown in Table 4, co-integration for the FRFs and the relationship between revenues-expenditures are accepted at a $1 \%$ statistical significance level.

In the next stage, we apply the two-sided fixed effect model with KraayDriscoll error terms to model long-run fiscal reaction functions. Additionally, Pesaran's (2006) CCEMG (Common Correlated Effects Mean Group Estimator) are implemented to estimate heterogeneous effects between the panel data set. As stated in Chudik and Pesaran, "the CCE method is robust to different types of cross section dependence of errors, possible unit roots in factors, and slope heterogeneity" (Chudik and Pesaran, 2015, p. 393). Table 5 shows the long-run fiscal reaction functions ${ }^{63}$.

Table 5 reveals a positive relationship between lagged public debt and the primary surplus-to-GDP ratio at a $1 \%$ statistical significance level. The explanatory power of the model is increased by adding the control variables (YVAR, GDP, and lagged primary surplus-to-GDP). The long-run positive relationship between two fiscal indicators indicates that, overall, fiscal sustainability is met in the EU. This finding is in line with the results in Afonso (2005), Prohl and Schineder (2006), and Afonso and Rault (2010).

In the next stage, we utilize the CCEMG model to estimate heterogeneous effects between cross-sections. For this purpose, we use crosssectional averages of explanatory and independent variables in the test. Table 6 shows the CCEMG test results.

${ }^{63}$ Primary surplus-to-GDP ratio is the dependent variable in the model. Year is selected as the control variable. Dummy variables produced by the outputs of Table 4. 
Table 5. Long-Run Fiscal Reaction Functions

\begin{tabular}{lcccc}
\hline Variables & $\mathbf{( 1 )}$ & $\mathbf{( 2 )}$ & $\mathbf{( 3 )}$ & $\mathbf{( 4 )}$ \\
\hline Lagged Public Debt-to-GDP & 0.0272 & 0.0272 & 0.00242 & 0.00228 \\
& $(0.006)$ & $(0.006)$ & $(0.005)$ & $(0.004)$ \\
\hline YVAR & & 0.0045 & & 0.00352 \\
& & $(0.01)$ & & $(0.008)$ \\
\hline GVAR & & 0.12 & & -0.0915 \\
& & $(0.01)$ & & $(0.01)$ \\
\hline Lagged Primary Surplus-to-GDP & & 0.587 & 0.533 \\
& & & $(0.032)$ & $(0.031)$ \\
\hline R-Square (Within) & 0.339 & 0.441 & 0.584 & 0.635
\end{tabular}

Notes: Primary surplus to GDP is the dependent variable in the long regression models 1-4. Column 1 is estimated with a fixed effect regression where the lagged public debt to GDP is the independent variable. Column 2 is estimated with a fixed effect regression in which the lagged public debt to GDP is the independent variable, and YVAR and GVAR are the control variables. Column 3 is estimated with a fixed effect regression where the lagged public debt to GDP and lagged primary surplus to GDP are the independent variables. Column 4 is estimated with a fixed effect regression where the lagged public debt to GDP and lagged primary surplus to GDP are the independent variables and YVAR and GVAR are the control variables.

Source: Authors' representation

\section{Table 6. CCEMG Test Results}

\begin{tabular}{|c|c|c|c|c|}
\hline Variables & (1) & (2) & (3) & (4) \\
\hline $\begin{array}{l}\text { Cross-sectional averages of lagged } \\
\text { public debt-to-GDP ratios }\end{array}$ & $\begin{array}{r}0.065 \\
(0.02)\end{array}$ & $\begin{array}{r}0.047 \\
(0.01)\end{array}$ & $\begin{array}{r}0.076 \\
(0.02)\end{array}$ & $\begin{array}{r}0.046 \\
(0.02)\end{array}$ \\
\hline Cross-sectional averages of YVAR & & $\begin{array}{r}6.352 \\
(6.01)\end{array}$ & & $\begin{array}{r}3.079 \\
(3.008)\end{array}$ \\
\hline Cross-sectional averages of GVAR & & $\begin{array}{r}-9.596 \\
(0.01)\end{array}$ & & $\begin{array}{r}-10.02 \\
(6.48)\end{array}$ \\
\hline $\begin{array}{l}\text { Cross-sectional averages of lagged } \\
\text { primary } \\
\text { Surplus-to-GDP ratios }\end{array}$ & & & $\begin{array}{c}0.319 \\
(0.04)\end{array}$ & $\begin{array}{r}-0.017 \\
(0.04)\end{array}$ \\
\hline Constant & $\begin{array}{r}-0.004 \\
(0.01)\end{array}$ & $\begin{array}{r}-0.007 \\
(0.01)\end{array}$ & $\begin{array}{r}0.001 \\
(0.01)\end{array}$ & $\begin{aligned}-0.008 \\
(0.01)\end{aligned}$ \\
\hline
\end{tabular}

Source: Authors' representation

As shown in Table 6, common unobserved factors influence fiscal policy distinctively for different EU states.

In the final stage of the study, we analyze fiscal sustainability for the PIIGS. Table 7 presents Pesaran's (2004) test results for the PIIGS. 
Table 7. CD Test Results for the PIIGS

\begin{tabular}{lc}
\hline Variables & CD Test \\
\hline Primary Surplus-to-GDP Ratios & $8.862^{* * *}$ \\
\hline Public Debt-to-GDP Ratios & $13.181^{* * *}$ \\
\hline Government Revenues (GDP \%) & 1.386 \\
\hline Government Expenditures (GDP \%) & $9.387^{* * *}$ \\
\hline YVAR & $9.603^{* * *}$ \\
\hline GVAR & $9.311^{* * *}$
\end{tabular}

Note: ${ }^{* * *},{ }^{* * *}$ represent $10 \%, 5 \%$ and $1 \%$ significance levels, respectively.

Source: Authors' representation

As presented in Table 7, the CD test rejects cross-sectional independence for all series except government revenues ${ }^{64}$. In the next step, we test the stationary of the variables by employing Peseran's (2006) CADF test. Table 8 presents the CADF test results for PIIGS countries.

Table 8. CADF Test Results for the PIIGS

\begin{tabular}{lll}
\hline \multicolumn{3}{c}{ CADF Test } \\
\hline Variables & Constant & Constant + Trend \\
\hline Primary Surplus-to-GDP Ratios & $-2.012(0.281)$ & $-2.406(0.409)$ \\
\hline Public Debt-to-GDP Ratios & $-1.639(0.610)$ & $-2.627(0.223)$ \\
\hline Government Revenues (GDP \%) & $-1.940(0.339)$ & $-1.761(0.907)$ \\
\hline Government Expenditures (GDP \%) & $-3.175(0.001)$ & $-3.035(0.041)$ \\
\hline YVAR & $-2.488(0.041)$ & $-3.236(0.013)$ \\
\hline GVAR & $-3.440(0.000)$ & $-3.382(0.005)$
\end{tabular}

Note: ${ }^{* * *},{ }^{* * *}$ represent $10 \%, 5 \%$ and $1 \%$ significance levels, respectively.

Source: Authors' representation

As shown in Table 8, with and without trend, all series are non-stationary except for government expenditure. YVAR and GVAR are stationary at least at 5\% significance level. Since we could not detect a long-run relationship between primary surplus-to-GDP ratio and other variables (transversality condition is not met), fiscal policy is not sustainable for the PIIGS countries in 1995-2018. This finding is in line with the results obtained in Brady and Magazzino (2018), which detected the absence of sustainability for the PIIGS in 1980-2015.

64 The null hypothesis (cross-sectional independence) is accepted at 0.166 statistical significance level. 


\section{Conclusions}

This study analyzes fiscal sustainability for 26 EU states and PIIGS by utilizing the model-based approach of Bohn (2008). Additionally, owing to the more unfavorable effects of the ESDC on the fiscal structure of the PIIGS compared to other EU states, we concentrate on fiscal sustainability for the EU overall and the PIIGS, distinctly. We utilize the Westerlund panel co-integration test to detect the long-run relationship between government revenues and government expenditure. Furthermore, we employ a two-sided fixed effect model with Kraay-Driscoll error terms to model long-run fiscal reaction functions. Estimations of this model indicate a positive relationship between primary surplus-to-GDP and lagged public debt and accordingly indicate that fiscal policy is sustainable in the EU, overall. This finding is consistent with the results in the related studies of Afonso (2005), Prohl and Schineder (2006), Afonso and Rault (2010) and verifies our research hypothesis which posits fiscal sustainability for the EU, overall.

Additionally, model estimations of the Pesaran's (2006) CCEMG model reveal that common unobserved factors influence fiscal policy distinctively for different EU states.

In the final stage of the study, we investigate fiscal sustainability for PIIGS countries. Since the transversality condition is not met for the PIIGS, it is found that the fiscal policy is not sustainable for PIIGS countries in the period 1995-2018. This finding is in line with the previous studies such as Brady and Magazzino (2018) and Neto (2020) and confirms the validity of another hypothesis of the study that assumes the absence of fiscal sustainability for PIIGS countries.

Our main contribution to the extant literature is two-folded. First, we examine a crucial policy challenge, namely fiscal sustainability, for a large panel set of EU states by allowing slope heterogeneity and cross-sectional dependence in dynamic panel models in a period that covers the GFC and the ESDC. Second, we obtain the long-term fiscal reaction functions (FRFs) to detect unobserved heterogeneous business and fiscal policy cyclical effects.

Our study proposes important policy implications. First, due to the adverse effects of financial/real crises on fiscal sustainability, the authorities should closely monitor fiscal indicators during tranquil and turmoil times. For this purpose, a robust and effective regulatory framework can be helpful. Second, performing a sustainable and autonomous fiscal policy reflecting the local conditions of the EU state is important. Third, since the fiscal sustainability criterion is not met for the PIIGS over the analyzed period, the EU authorities should enact macroprudential policies for sustaining stability in the fiscal stance of the PIIGS.

Our analysis can be extended into future research by taking into account the time-varying dynamics of fiscal sustainability. It is our belief that this type of analysis will shed light on the dynamic nature of fiscal positions of states and provide valuable insights for authorities. 


\section{References}

Afonso, A. (2005), Fiscal Sustainability: The Unpleasant European Case, Public Finance Analysis, 61(1), pp. 19-44.

Afonso, A. and Rault, C. (2010), What Do We Really Know About Fiscal Sustainability in the EU? A Panel Data Diagnostic, Review of World Economics, 145(4), pp. 731-755. https://doi.org/10.1007/s10290-009-0034-1

Alexakis, C. and Pappas, V. (2018), Sectoral dynamics of financial contagion in Europe-The cases of the recent crises episodes, Economic Modelling, 73, pp. 222-239. https://doi.org/10.1016/j.econmod.2018.03.018

Andrews, D. (2005), Cross Section Regression with Common Shocks, Econometrica, 73(5), pp. 1551-1585. https://doi.org/10.1111/j.1468-0262.2005.00629.x

Barro, R.J. (1986), US deficits since World War I, The Scandinavian Journal of Economics, 88(1), pp. 195-222.

Bergman, M. (2001), Testing Government Solvency and The No Ponzi Game Condition, Applied Economics Letters, 8(1), pp. 27-29. https://doi.org/10.1080/ $\underline{135048501750041240}$

Berrittella, M. and Zhang, J. (2015), Fiscal sustainability in the EU: From the short-term risk to the long-term challenge, Journal of policy modeling,37(2), pp. 261-280. https://doi.org/10.1016/j.jpolmod.2015.02.004

Blanchard, O.J. (1990), Suggestions for A New Set of Fiscal Indicators, No. 79, OECD Economics Department Working Papers, April. https://doi.org/10.1787/18151973

Blanchard, O.J., Chouraqui, J.C., Hagemann, R. and Sartor, N. (1991), The Sustainability of Fiscal Policy: New Answers to An Old Question, No: R1547, NBER Working Paper, National Bureau of Economic Research (retrieved from https://www.oecd.org/ economy/outlook/34288870.pdf).

Bohn, H. (1995), The Sustainability of Budget Deficits in A Stochastic Economy, Journal of Money, Credit and Banking, 27(1), pp. 257-271.

Bohn, H. (1998), The Behavior of US Public Debt and Deficits, Quarterly Journal of Economics, 113(3), pp. 949-963.

Bohn, H. (2008), The Sustainability of Fiscal Policy in The United States, in: Neck, R. and Sturm, J.E. (eds.), Sustainability of Public Debt, Cambridge: MIT Press, pp. 15-49.

Brady, G.L. and Magazzino, C. (2018), Fiscal Sustainability in the EU, Atlantic Economic Journal, 46(3), pp. 297-311. https://doi.org/10.1007/s11293-018-9588-4

Buiter, W.H. (1985), A guide to public sector debt and deficits, Economic policy, 1(1), pp. 13-61.

Calvo, G.A., Izquierdo, A. and Talvi, E. (2003), Sudden Stops, the Real Exchange Rate, and Fiscal Sustainability: Argentina's Lessons, No: w9828, NBER Working Paper, National Bureau of Economic Research (retrieved from https://www.nber.org/papers/w9828). 
Caporale, G.M. (1995), Bubble Finance and Debt Sustainability: A Test of The Government's Intertemporal Budget Constraint, Applied Economics, 27(12), pp. 1135-1143.

Chudik, A. and Pesaran, M.H. (2013), Large Panel Data Models with Cross-Sectional Dependence: A Survey, No: 13.15, CAFE Research Paper.

Chudik, A. and Pesaran, M.H. (2015). Common correlated effects estimation of heterogeneous dynamic panel data models with weakly exogenous regressors, Journal of Econometrics, 188(2), 393-420. https://doi.org/10.1016/j.jeconom.2015.03.007

Claeys, P. (2007), Sustainability of EU Fiscal Policies: A Panel Test, Journal of Economic Integration, 22(1), pp. 112-127. https://doi.org/10.11130/jei.2007.22.1.112

Claeys, P., Ramos, R. and Suriñach, J. (2008), Fiscal Sustainability Across Government Tiers, International Economics and Economic Policy, 5(1-2), pp. 139-163. https://doi.org/10.1007/s10368-008-0112-1

Dolenc, P. and Stubelj, I. (2010). Fiscal sustainability in EU and current financial/economic crisis, International journal of sustainable economy, 2(1), pp. 80-91. https://doi.org/10.1504/IJSE.2010.029942

Domar, H. (1944), The Burden of Debt and National Income, American Economic Review, 34(4), pp. 798-827.

Dragutinović, R., Glavaški, O. and Pucar, E.B. (2019), Fiscal Sustainability in Flow Model: Panel Cointegration Approach for the EU-28, Ovidius University Annals, Economic Sciences Series, 19(1), pp. 15-24.

Elliot, G. and Kearney, C. (1988), The Intertemporal Government Budget Constraint and Tests for Bubbles, No: 8809, Research Discussion Paper, Reserand Bank of Australia.

European Commission (2017), European Semester Thematic Factsheet Sustainability of Public Finances (retrieved from https://ec.europa.eu/info/sites/info/files/europeansemester_thematic-factsheet_public-finance-sustainability_en_0.pdf).

Feld, L.P., Köhler, E.A. and Wolfinger, J. (2020), Modeling Fiscal Sustainability in Dynamic Macro-Panels with Heterogeneous Effects: Evidence from German Federal States, International Tax and Public Finance, 27(1), pp. 215-239. https://doi.org/10.1007/s10797-019-09548-7

Ghatak, S. and Sánchez-Fung, J.R. (2007), Is Fiscal Policy Sustainable in Developing Economies?, Review of Development Economics, 11(3), pp. 518-530. https://doi.org/10.1111/j.1467-9361.2006.00358.x

Greiner, A. and Semmler, W. (1999), An Inquiry into the Sustainability of German Fiscal Policy: Some Time-Series Tests, Public Finance Review, 27(2), pp. 220-236. https://doi.org/10.1177/109114219902700205

Hakkio, C.S. and Rush, M. (1991), Is the Budget Deficit too Large?, Economic Inquiry, 29(3), pp. 429-445. https://doi.org/10.1111/j.1465-7295.1991.tb00837.x

Hamilton, J. and Flavin, M. (1986), On the Limitations of Government Borrowing: A Framework for Empirical Testing, American Economic Review, 76(4), pp. 808-819. 
Hamilton, J.D. and Flavin, M. (1985), On the Limitations of Government Borrowing: A Framework for Empirical Testing, The American Economic Review, 76(4), pp. 808819.

Hansen, L.P. (1982), Large Sample Properties of Generalized Method of Moments Estimators, Econometrica: Journal of the Econometric Society, 50(4), pp. 1029-1054.

Hodrick, R.J. and Prescott, E.C. (1997), Postwar US Business Cycles: An Empirical Investigation, Journal of Money, Credit, and Banking, 29(1), pp. 1-16.

Kremers, J. (1988), The Long-Run Limits of U.S. Federal Debt, Economics Letters, 28(3), pp. 259-262.

Lee, K.W., Kim, J.H. and Sung, T. (2018), A test of fiscal sustainability in the EU countries, International Tax and Public Finance, 25(5), pp. 1170-1196. https://doi.org/10.1007/s10797-018-9488-1

MacDonald, R. and Speight, A.E. (1990), The Intertemporal Government Budget Constraint in the UK, 1961-1986, The Manchester School of Economic \& Social Studies, 58(4), pp. 329-347.

Mackiewicz-Łyziak, J. and Łyziak, T. (2019), A new test for fiscal sustainability with endogenous sovereign bond yields: Evidence for EU economies, Economic Modelling, 82, pp. 136-151. https://doi.org/10.1016/j.econmod.2019.01.001

Mahdavi, S. (2014), Bohn's Test of Fiscal Sustainability of The American State Governments, Southern Economic Journal, 80(4), pp. 1028-1054. https://doi.org/10.4284/0038-4038-2012.223

Makrydakis, S., Tzavalis, E. and Balfoussias, A. (1999), Policy Regime Changes and The Long-Run Sustainability of Fiscal Policy: An Application to Greece, Economic Modelling, 16(1), pp. 71-86.

Mendoza, E. and Oviedo, P.M. (2003), Public Debt Sustainability Under Uncertainty, Mimeographed Document, Washington, DC, United States: Inter-American Development Bank.

Neto, D. (2020), Tracking fiscal discipline. Looking for a PIIGS on the wing, International Economics, 163, pp. 147-154. https://doi.org/10.1016/j.inteco.2020.01.005

Pesaran, M. (2004), General Diagnostic Tests for Cross Section Dependence in Panels, IZA Discussion Paper, No: 1240.

Pesaran, M.H. (2007), A Simple Panel Unit Root Test in The Presence of Cross-Section Dependence, Journal of Applied Econometrics, 22(2), pp. 265-312. https://doi.org/10.1002/jae.951

Polat, G.E. and Polat, O. (2019), A Discussion on Fiscal Policies Implemented in EU During and After the Great Recession, in: Global Challenges in Public Finance and International Relations, IGI Global, pp. 143-159.

Potrafke, N. and Reischmann, M. (2015), Fiscal Transfers and Fiscal Sustainability, Journal of Money, Credit and Banking, 47(5), pp. 975-1005. https://doi.org/10.1111/jmcb.12231 
Prohl, S. and Schneider, F.G. (2006), Sustainability of Public Debt and Budget Deficit: Panel Cointegration Analysis for The European Union Member Countries, No. 0610, Working Paper, Johannes Kepler University of Linz, Department of Economics.

Ramos-Herrera, M.D.C. and Prats, M.A. (2020), Fiscal Sustainability in the European Countries: A Panel ARDL Approach and a Dynamic Panel Threshold Model, Sustainability, 12(20), p. 8505. https://doi.org/10.3390/su12208505

Sachs, J.D. (2002), Resolving the Debt Crisis Oo Low-Income Countries, Brookings Papers on Economic Activity, 2002(1), pp. 257-286.

Sakuragawa, M. and Hosono, K. (2011), Fiscal Sustainability in Japan, Journal of the Japanese and International Economies, 25(4), pp. 434-446. https://doi.org/10.1002/app5.133

Sarafidis, V. and Robertson, D. (2009), On the Impact of Error Cross-Sectional Dependence in Short Dynamic Panel Estimation, The Econometrics Journal, 12(1), pp. 62-81. https://doi.org/10.1111/j.1368-423X.2008.00260.X

Siriwardana, M.K.M. (1998), An Analysis of Fiscal Sustainability in Sri Lanka, Central Bank of Sri Lanka Staff Studies, 27-28, pp. 80-111.

Slack, E. and Richard, M.B. (2004), The Fiscal Sustainability of The Greater Toronto Area", No: 0405, ITP Paper, International Tax Program, Institute for International Business, Joseph L. Rotman School of Management, University of Toronto.

Smith, G.W. and Zin, S.E. (1991), Persistent Deficits and the Market Value of Government Debt, Journal of Applied Econometrics, 6(1), pp. 31-44. https://doi.org/10.1002/jae.3950060104

Trehan, B. and Walsh, C. (1988), Common Trends, the Government's Budget Constraint, and Revenue Smoothing, Journal of Economic Dynamics and Control, 12(2-3), pp. 425444. https://doi.org/10.1016/0165-1889(88)90048-6

Trehan, B. and Walsh, C. E. (1991), Testing Intertemporal Budget Constraints: Theory and Applications to US Federal Budget and Current Account Deficits, Journal of Money, Credit and Banking, 23(2), pp. 206-223. https://doi.org/10.2307/1992777

Westerlund, J. (2007), Testing for Error Correction in Panel Data, Oxford Bulletin of Economics and Satistics, 69(6), pp. 709-748. https://doi.org/10.1111/j.14680084.2007.00477.x

Wilcox, D. (1989), The Sustainability of Government Deficits: Implications of the PresentValue Borrowing Constraint, Journal of Money, Credit, and Banking, 21(3), pp. 291 306. https://doi.org/10.1007/S11293-018-9588-4 


\section{Appendix}

Figure A.1. Public Debt to GDP Ratios for 26 EU States in 1995-2018

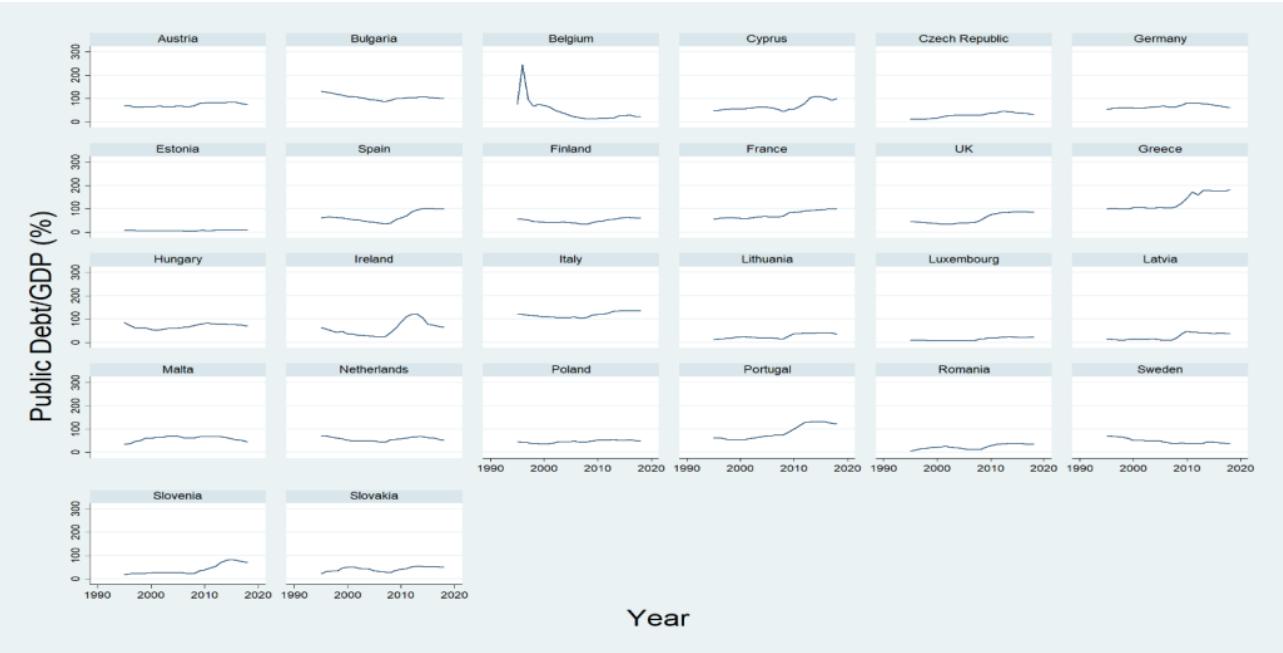

Source: Authors' representation

Table A.1. Summary Statistics for Public Debt-to-GDP Ratios

\begin{tabular}{llllllll}
\hline Countries & Mean & Sd & Median & Min & Max & Skewness & Kurtosis \\
\hline Austria & 72.63275 & 7.78701 & 68.481 & 63.493 & 84.894 & 0.391911 & -1.68714 \\
\hline Belgium & 105.8945 & 11.13531 & 104.848 & 87.325 & 131.295 & 0.728142 & -0.10921 \\
\hline Bulgaria & 46.27508 & 48.88117 & 26.84 & 13.025 & 244.502 & 2.755371 & 8.390616 \\
\hline Cyprus & 69.36971 & 21.13907 & 59.89 & 45.557 & 109.221 & 0.849583 & -0.97934 \\
\hline Czech Republic & 28.62542 & 10.4739 & 28.275 & 11.647 & 44.909 & -0.16866 & -1.22328 \\
\hline Germany & 66.6245 & 8.163966 & 65.144 & 54.902 & 82.382 & 0.552849 & -1.01503 \\
\hline Estonia & 6.951708 & 2.125541 & 6.519 & 3.766 & 10.555 & 0.357344 & -1.32387 \\
\hline Spain & 66.18788 & 21.98314 & 61.173 & 35.765 & 100.7 & 0.425575 & -1.3184 \\
\hline Finland & 48.28913 & 9.195059 & 46.8665 & 32.561 & 63.015 & 0.102608 & -1.32394 \\
\hline France & 74.91229 & 15.85861 & 66.661 & 56.106 & 98.414 & 0.360255 & -1.70056 \\
\hline United Kingdom & 57.49004 & 21.70199 & 44.493 & 34.017 & 86.923 & 0.360863 & -1.78374 \\
\hline Greece & 129.7295 & 34.38865 & 107.238 & 97.425 & 181.21 & 0.514139 & -1.66234 \\
\hline Hungary & 68.70883 & 9.5105 & 70.8205 & 52.253 & 84.143 & -0.10147 & -1.47112 \\
\hline Ireland & 59.04063 & 30.6903 & 52.9145 & 23.786 & 119.913 & 0.682899 & -0.79336 \\
\hline Italy & 117.8975 & 11.36798 & 116.6845 & 103.873 & 135.358 & 0.392619 & -1.40799 \\
\hline Lithuania & 26.23142 & 10.59469 & 22.795 & 11.526 & 42.712 & 0.260232 & -1.65255 \\
\hline Luxembourg & 13.62196 & 6.560614 & 9.581 & 6.942 & 23.686 & 0.318766 & -1.76971 \\
\hline Latvia & 23.88654 & 14.23028 & 13.985 & 8.048 & 47.27 & 0.334592 & -1.80089 \\
\hline Malta & 59.87117 & 10.32421 & 62.8875 & 34.365 & 71.918 & -0.97708 & -0.14642 \\
\hline the Netherlands & 57.91171 & 8.44236 & 57.736 & 42.981 & 73.092 & 0.053882 & -1.21356 \\
\hline Poland & 46.76158 & 5.666694 & 46.768 & 36.453 & 55.692 & -0.21827 & -1.12644 \\
\hline Portugal & 87.45267 & 30.75842 & 73.2035 & 54.193 & 132.941 & 0.436444 & -1.63162 \\
\hline Romania & 24.25233 & 10.35522 & 22.298 & 6.609 & 39.216 & 0.033716 & -1.4856 \\
\hline Sweden & 48.33283 & 10.68541 & 44.576 & 37.35 & 69.53 & 0.850315 & -0.69178 \\
\hline Slovenia & 40.30508 & 22.63417 & 26.838 & 18.237 & 82.586 & 0.815658 & -1.09926 \\
\hline & & & & & & & \\
\hline & & & & & & &
\end{tabular}




\begin{tabular}{llllllll}
\hline Slovakia & 42.02163 & 9.619733 & 43.353 & 21.591 & 54.708 & -0.36882 & -1.22742 \\
\hline
\end{tabular}

Source: Authors' representation

Table A.2. Summary Statistics for Primary Surplus-to-GDP Ratios

\begin{tabular}{llllllll}
\hline Countries & Mean & Sd & Median & Min & Max & Skewness & Kurtosis \\
\hline Austria & 0.520208 & 1.336463 & 0.776 & -2.187 & 2.944 & -0.64711 & -0.3831 \\
\hline Belgium & 2.845583 & 2.749696 & 3.2435 & -1.543 & 6.804 & -0.04752 & -1.55665 \\
\hline Bulgaria & 1.94125 & 3.003467 & 2.307 & -4.565 & 7.578 & -0.23933 & -0.37641 \\
\hline Cyprus & -0.27383 & 2.785919 & -0.8115 & -5.528 & 6.032 & 0.364086 & -0.6297 \\
\hline Czech Republic & -2.06783 & 2.915743 & -1.897 & -11.431 & 2.309 & -1.16588 & 2.159072 \\
\hline Germany & 0.724542 & 1.986266 & 1.2185 & -5.926 & 2.938 & -1.47818 & 2.660799 \\
\hline Denmark & 2.916542 & 2.489089 & 2.9255 & -1.681 & 7.011 & -0.11739 & -1.03921 \\
\hline Estonia & 0.443042 & 1.562541 & 0.2665 & -2.921 & 3.018 & -0.26066 & -0.46144 \\
\hline Spain & -0.96258 & 3.865836 & -0.303 & -9.559 & 3.735 & -0.77016 & -0.59908 \\
\hline Finland & 2.373917 & 3.456064 & 1.8275 & -2.091 & 9.565 & 0.304624 & -1.3107 \\
\hline France & -0.91529 & 1.605343 & -0.8165 & -4.631 & 1.634 & -0.45666 & -0.0343 \\
\hline United Kingdom & -1.28446 & 2.933709 & -1.0735 & -8.252 & 3.788 & -0.38414 & -0.19911 \\
\hline Greece & -1.10121 & 3.846033 & -0.9745 & -10.108 & 4.277 & -0.62856 & -0.3624 \\
\hline Hungary & -0.02004 & 2.418205 & 0.2235 & -5.366 & 4.673 & -0.5144 & -0.25318 \\
\hline Ireland & -0.46442 & 7.625808 & 1.619 & -29.229 & 6.796 & -2.3337 & 5.82702 \\
\hline Italy & 2.290542 & 1.666017 & 1.8555 & -0.713 & 6.156 & 0.455562 & -0.52159 \\
\hline Lithuania & -1.64258 & 3.179699 & -1.008 & -11.02 & 1.569 & -1.43127 & 1.38109 \\
\hline Luxembourg & 2.28475 & 1.896514 & 2.1355 & -1.067 & 6.268 & 0.359424 & -0.46299 \\
\hline Latvia & -1.0055 & 2.387156 & -0.109 & -7.969 & 2.286 & -1.52177 & 1.817169 \\
\hline Malta & -0.60342 & 2.916365 & -0.2275 & -6.371 & 5.232 & -0.30389 & -0.5038 \\
\hline the Netherlands & 0.656792 & 2.431319 & 1.4725 & -3.657 & 4.459 & -0.35651 & -1.20364 \\
\hline Poland & -1.15879 & 1.618111 & -1.137 & -4.907 & 1.438 & -0.6415 & 0.001101 \\
\hline Portugal & -1.33092 & 2.572381 & -0.5385 & -8.457 & 2.936 & -1.01507 & 0.957408 \\
\hline Romania & -1.24525 & 2.181725 & -0.533 & -7.629 & 1.022 & -1.35436 & 1.13086 \\
\hline Sweden & 2.12275 & 2.128946 & 1.7195 & -1.917 & 6.515 & 0.170995 & -0.87405 \\
\hline Slovenia & -1.336 & 3.169952 & -0.2865 & -12.034 & 2.765 & -1.61323 & 2.985154 \\
\hline Slovakia & -2.60475 & 2.504716 & -1.652 & -8.589 & 0.487 & -0.87865 & -0.35177 \\
\hline Source: Aut & $r-p r 59$ & & & & \\
\hline
\end{tabular}

Source: Authors' representation

Table A.3. Summary Statistics for Public Revenues

\begin{tabular}{llllllll}
\hline Countries & Mean & Sd & Median & Min & Max & Skewness & Kurtosis \\
\hline Austria & 49.1465 & 0.830716 & 48.962 & 47.844 & 51.121 & 0.484585 & -0.42762 \\
\hline Belgium & 50.09517 & 1.27658 & 49.7355 & 48.137 & 52.987 & 0.732542 & -0.54219 \\
\hline Bulgaria & 36.20542 & 3.854085 & 37.603 & 26.253 & 41.677 & -0.84981 & 0.112066 \\
\hline Cyprus & 35.52492 & 3.646771 & 36.5985 & 29.404 & 40.819 & -0.34061 & -1.29733 \\
\hline Czech Republic & 39.64013 & 1.321443 & 39.523 & 37.39 & 42.461 & 0.20689 & -0.87423 \\
\hline Germany & 44.88363 & 0.948865 & 44.9555 & 43.457 & 46.493 & 0.019534 & -1.29183 \\
\hline Estonia & 37.96404 & 1.907047 & 38.2885 & 34.816 & 43.416 & 0.72558 & 0.714501 \\
\hline Spain & 38.17283 & 1.332001 & 38.1555 & 34.955 & 41.141 & -0.03335 & 0.285516 \\
\hline Finland & 53.06879 & 1.378186 & 52.6425 & 51.333 & 56.25 & 0.527529 & -0.90471 \\
\hline France & 51.06 & 1.459652 & 50.489 & 49.255 & 53.609 & 0.625195 & -1.22864 \\
\hline United Kingdom & 36.90888 & 1.737837 & 37.48 & 33.16 & 39.183 & -0.84982 & -0.45074 \\
\hline Greece & 42.09833 & 4.241003 & 40.441 & 36.269 & 49.487 & 0.526586 & -1.30744 \\
\hline Hungary & 44.70058 & 1.948324 & 44.4795 & 41.711 & 48.661 & 0.238734 & -0.99269 \\
\hline Ireland & 33.668 & 3.784232 & 34.114 & 25.41 & 38.743 & -0.93438 & -0.08266 \\
\hline
\end{tabular}




\begin{tabular}{llllllll}
\hline Italy & 45.48375 & 1.446122 & 45.442 & 43.159 & 48.097 & 0.26107 & -1.04683 \\
\hline Lithuania & 34.54033 & 1.732041 & 34.076 & 32.313 & 38.519 & 0.998495 & -0.0377 \\
\hline Luxembourg & 43.41617 & 0.859169 & 43.4055 & 41.597 & 45.056 & -0.12879 & -0.70975 \\
\hline Latvia & 35.42108 & 1.752873 & 35.8155 & 32.089 & 38.096 & -0.27441 & -1.31203 \\
\hline Malta & 37.37233 & 2.152138 & 38.4845 & 32.267 & 39.803 & -0.70617 & -0.80252 \\
\hline the Netherlands & 43.01392 & 0.976667 & 43.0225 & 41.397 & 45.146 & 0.27214 & -0.42267 \\
\hline Poland & 40.24817 & 1.963796 & 40.0135 & 37.577 & 46.604 & 1.448487 & 2.337841 \\
\hline Portugal & 40.98363 & 1.995729 & 40.5665 & 37.449 & 44.817 & 0.202584 & -1.01755 \\
\hline Romania & 32.79758 & 1.475183 & 32.8895 & 29.602 & 35.508 & -0.38736 & -0.41096 \\
\hline Slovakia & 38.75604 & 3.037352 & 38.751 & 34.33 & 44.894 & 0.227988 & -1.12324 \\
\hline Slovenia & 44.41454 & 0.717105 & 44.3025 & 43.066 & 45.863 & 0.24236 & -0.71264 \\
\hline Sweden & 53.00829 & 2.904502 & 52.7015 & 49.323 & 58.276 & 0.437828 & -1.25449 \\
\hline SOurce: Auth
\end{tabular}

Source: Authors' representation

Table A.3. Summary Statistics for Public Expenditures

\begin{tabular}{llllllll}
\hline Countries & Mean & Sd & Median & Min & Max & Skewness & Kurtosis \\
\hline Austria & 51.63492 & 1.830111 & 51.242 & 48.65 & 55.806 & 0.645609 & -0.07391 \\
\hline Belgium & 52.11233 & 2.379941 & 51.886 & 48.563 & 56.478 & 0.268817 & -1.15285 \\
\hline Bulgaria & 37.01917 & 3.163807 & 36.931 & 30.361 & 43.323 & -0.09445 & -0.65506 \\
\hline Cyprus & 38.55938 & 4.184284 & 38.475 & 30.933 & 49.353 & 0.383683 & -0.11646 \\
\hline Czech Republic & 42.77771 & 3.004084 & 42.1765 & 38.944 & 52.929 & 1.852946 & 3.620187 \\
\hline Germany & 46.6805 & 2.570984 & 46.806 & 43.398 & 55.117 & 1.262924 & 2.250085 \\
\hline Estonia & 37.73138 & 2.795343 & 38.5635 & 33.447 & 45.595 & 0.451929 & 0.474509 \\
\hline Spain & 41.98079 & 3.121352 & 41.457 & 38.375 & 48.656 & 0.432663 & -1.13843 \\
\hline Finland & 52.65317 & 4.137582 & 53.3615 & 46.57 & 61.051 & 0.198604 & -1.1744 \\
\hline France & 54.66283 & 1.983615 & 54.67 & 51.652 & 57.228 & 0.01522 & -1.70323 \\
\hline United Kingdom & 40.64838 & 3.81258 & 40.9465 & 35.132 & 47.376 & 0.139424 & -1.1749 \\
\hline Greece & 48.88388 & 4.476975 & 47.0155 & 43.706 & 62.37 & 1.275942 & 1.07971 \\
\hline Hungary & 49.5485 & 1.834857 & 49.389 & 46.654 & 55.23 & 0.828318 & 1.652734 \\
\hline Ireland & 36.604 & 8.376235 & 34.2285 & 25.358 & 65.08 & 1.521625 & 3.110642 \\
\hline Italy & 48.80163 & 1.698491 & 48.5345 & 46.536 & 51.619 & 0.254979 & -1.48726 \\
\hline Lithuania & 37.39321 & 4.310218 & 35.4035 & 33.169 & 50.273 & 1.327135 & 1.076919 \\
\hline Luxembourg & 41.52467 & 2.041749 & 41.655 & 37.809 & 45.147 & -0.21991 & -0.89937 \\
\hline Latvia & 37.41217 & 2.983817 & 37.47 & 33.546 & 45.311 & 1.106388 & 0.769616 \\
\hline Malta & 40.977 & 2.116459 & 41.5495 & 35.863 & 45.188 & -0.93894 & 0.654861 \\
\hline the Netherlands & 44.79908 & 2.661613 & 43.9565 & 42.053 & 53.721 & 1.507892 & 2.649881 \\
\hline Poland & 44.17113 & 2.330868 & 43.948 & 41.108 & 51.14 & 1.041872 & 1.126095 \\
\hline Portugal & 45.91917 & 3.073974 & 45.2935 & 42.459 & 51.899 & 0.606921 & -1.06142 \\
\hline Romania & 36.06317 & 2.095446 & 35.4995 & 33.167 & 39.99 & 0.482299 & -1.13359 \\
\hline Sweden & 53.01929 & 3.860444 & 52.0995 & 49.272 & 63.487 & 1.270241 & 0.679656 \\
\hline Slovenia & 47.83088 & 3.617285 & 47.0875 & 43.409 & 60.268 & 1.625187 & 3.333209 \\
\hline Slovakia & 43.51146 & 4.481852 & 42.486 & 36.381 & 53.27 & 0.490443 & -0.47772 \\
\hline Source: Auth & & & & & &
\end{tabular}

Source: Authors' representation

Table A.5. Summary Statistics for the YVAR

\begin{tabular}{llllllll}
\hline Countries & Mean & Sd & Median & Min & Max & Skewness & Kurtosis \\
\hline Austria & 0.0002093 & 0.0043154 & 0.0000169 & -0.0089378 & 0.0079596 & -0.2328418 & -0.3196051 \\
\hline Belgium & 0.0001297 & 0.0030966 & 0.0003726 & -0.0064537 & 0.0062822 & -0.1199903 & -0.4288173 \\
\hline Bulgaria & 0.0028300 & 0.0569303 & 0.0043287 & -0.1455904 & 0.1017655 & -0.6367742 & 0.7436966 \\
\hline Cyprus & 0.0176955 & 0.1713811 & 0.0172170 & -0.2760524 & 0.2710244 & -0.1015218 & -1.3840273 \\
\hline Czech Republic & 0.0000201 & 0.0005170 & 0.0000177 & -0.0009450 & 0.0007352 & -0.4299255 & -1.0363270 \\
\hline
\end{tabular}




\begin{tabular}{llllllll}
\hline Germany & 0.0000027 & 0.0003256 & -0.0000144 & -0.0004879 & 0.0009335 & 0.7293199 & 0.6267472 \\
\hline Spain & 0.0002223 & 0.0024946 & 0.0002377 & -0.0039824 & 0.0046773 & 0.0337893 & -1.0980372 \\
\hline Estonia & 0.0398156 & 0.2493106 & 0.0827321 & -0.5395405 & 0.4367329 & -0.6063741 & -0.1013679 \\
\hline Finland & 0.0017415 & 0.0200665 & 0.0002875 & -0.0324369 & 0.0493260 & 0.4866343 & -0.1019690 \\
\hline France & 0.0000312 & 0.0007596 & 0.0001311 & -0.0012658 & 0.0015083 & 0.2305204 & -0.8237323 \\
\hline United Kingdom & 0.0000387 & 0.0008287 & 0.0001001 & -0.0014908 & 0.0015177 & -0.1869487 & -0.9294196 \\
\hline Greece & 0.0039126 & 0.0307160 & 0.0130400 & -0.0466685 & 0.0496205 & -0.3100291 & -1.4545022 \\
\hline Hungary & 0.0000079 & 0.0000990 & 0.0000322 & -0.0001823 & 0.0001591 & -0.4588502 & -1.0407888 \\
\hline Ireland & 0.0003790 & 0.0183446 & -0.0087677 & -0.0205802 & 0.0352062 & 0.6128342 & -1.2366490 \\
\hline Italy & 0.0000469 & 0.0012082 & 0.0001700 & -0.0021220 & 0.0021637 & -0.0976248 & -1.1966810 \\
\hline Lithuania & 0.0147243 & 0.0954383 & 0.0261921 & -0.2128091 & 0.1656048 & -0.8210789 & 0.1600669 \\
\hline Luxembourg & 0.0044977 & 0.0481954 & -0.0003413 & -0.0910499 & 0.1168259 & 0.3900361 & -0.2024112 \\
\hline Latvia & 0.0408184 & 0.2144462 & 0.0828143 & -0.4737276 & 0.3793383 & -0.8934069 & 0.0226164 \\
\hline Malta & -0.0257769 & 0.3989028 & -0.0629167 & -0.6608071 & 0.5751547 & 0.0680674 & -1.4714410 \\
\hline the Netherlands & 0.0001736 & 0.0030079 & -0.0004152 & -0.0042793 & 0.0078619 & 0.7479435 & 0.1408927 \\
\hline Poland & -0.0001393 & 0.0013831 & -0.0000280 & -0.0029558 & 0.0021751 & -0.2347834 & -0.6168797 \\
\hline Portugal & 0.0007488 & 0.0144183 & -0.0024771 & -0.0173748 & 0.0351135 & 0.6625235 & -0.6343177 \\
\hline Romania & 0.0000920 & 0.0062316 & 0.0012329 & -0.0155536 & 0.0097956 & -0.7965211 & 0.3076202 \\
\hline Slovakia & -0.0007222 & 0.0544189 & 0.0010801 & -0.0926837 & 0.0900365 & -0.0637829 & -0.9480216 \\
\hline Slovenia & 0.0084092 & 0.0846076 & 0.0105468 & -0.1760483 & 0.1530673 & -0.4409620 & -0.3608880 \\
\hline Sweden & 0.0000191 & 0.0003473 & -0.0000007 & -0.0007199 & 0.0005731 & -0.1802881 & -0.6841371 \\
\hline Source: Authe & & & & & & &
\end{tabular}

Source: Authors' representation

Table A.6: Summary Statistics for the GVAR

\begin{tabular}{|c|c|c|c|c|c|c|c|}
\hline Countries & Mean & $\mathrm{Sd}$ & Median & Min & Max & Skewness & Kurtosis \\
\hline Austria & 0.0000161 & 0.0055877 & -0.0026809 & -0.0081751 & 0.0108202 & 0.6206481 & -0.9428087 \\
\hline Belgium & 0.0000206 & 0.0061038 & -0.0006642 & -0.0104958 & 0.0093036 & 0.0547350 & -1.3226942 \\
\hline Bulgaria & -0.0006274 & 0.0539304 & 0.0028287 & -0.1251246 & 0.0933897 & -0.3138772 & -0.3438977 \\
\hline Cyprus & -0.0016045 & 0.1479936 & -0.0057775 & -0.3126907 & 0.3850376 & 0.2441945 & 0.6024077 \\
\hline Czech Republic & 0.0000019 & 0.0009387 & -0.0001818 & -0.0010682 & 0.0031952 & 1.7265634 & 3.4107197 \\
\hline Germany & 0.0000022 & 0.0006913 & -0.0000913 & -0.0012323 & 0.0024200 & 1.6091854 & 4.0130326 \\
\hline Spain & 0.0000163 & 0.0028521 & 0.0001015 & -0.0043367 & 0.0074534 & 0.4399080 & -0.0381529 \\
\hline Estonia & 0.0039674 & 0.2136815 & -0.0584588 & -0.2453933 & 0.4866410 & 0.5243169 & -0.9680130 \\
\hline Finland & 0.0002275 & 0.0259209 & 0.0015600 & -0.0346861 & 0.0652255 & 0.6896444 & -0.1056695 \\
\hline France & 0.0000033 & 0.0007960 & -0.0001028 & -0.0011380 & 0.0014746 & 0.2624191 & -1.2422278 \\
\hline United Kingdom & -0.0000104 & 0.0016885 & -0.0001242 & -0.0021710 & 0.0034937 & 0.5235482 & -0.8728246 \\
\hline Greece & -0.0000069 & 0.0175100 & -0.0022754 & -0.0295026 & 0.0535104 & 0.9754887 & 1.5324621 \\
\hline Hungary & 0.0000002 & 0.0000710 & 0.0000062 & -0.0001296 & 0.0002197 & 0.7825029 & 1.8618801 \\
\hline Ireland & -0.0008909 & 0.0452973 & -0.0194554 & -0.0516146 & 0.1498201 & 1.5360311 & 2.5421517 \\
\hline Italy & 0.0000004 & 0.0010743 & -0.0002815 & -0.0012927 & 0.0022128 & 0.5402102 & -1.0061072 \\
\hline Lithuania & -0.0004650 & 0.1970349 & -0.0327335 & -0.3367391 & 0.6514859 & 1.3765862 & 2.7280997 \\
\hline Luxembourg & -0.0001667 & 0.0551922 & 0.0082512 & -0.1058546 & 0.0859188 & -0.3406202 & -0.9229618 \\
\hline Latvia & 0.0001014 & 0.1662050 & -0.0301232 & -0.2214259 & 0.3819633 & 1.0717766 & 0.2819546 \\
\hline Malta & -0.0108447 & 0.3031139 & 0.0147533 & -0.8390440 & 0.6504252 & -0.5227293 & 0.7238775 \\
\hline the Netherlands & 0.0000173 & 0.0047493 & -0.0015426 & -0.0058421 & 0.0162951 & 1.5975468 & 3.1258662 \\
\hline Poland & 0.0000236 & 0.0016891 & 0.0000336 & -0.0038292 & 0.0056615 & 0.8780091 & 3.7410639 \\
\hline Portugal & -0.0000195 & 0.0137795 & -0.0018464 & -0.0296866 & 0.0290178 & 0.1391020 & -0.3461749 \\
\hline Romania & -0.0000850 & 0.0045583 & -0.0011538 & -0.0079299 & 0.0092504 & 0.4346394 & -0.9148323 \\
\hline Slovakia & 0.0021976 & 0.0472464 & -0.0034019 & -0.0606918 & 0.1527646 & 1.4148753 & 2.3869985 \\
\hline Slovenia & 0.0000289 & 0.1055240 & -0.0168257 & -0.1337069 & 0.3223181 & 1.4375890 & 1.9974279 \\
\hline Sweden & 0.0000167 & 0.0012255 & 0.0002009 & -0.0020807 & 0.0025224 & 0.0351181 & -0.4178263 \\
\hline
\end{tabular}

Source: Authors' representation 